state of Alaska

Department of Natural Resources

DIVISION OF MINES AND MINERALS
PROPERTY OF

LIBRARY

STATE OF ALASKA

DIVISION OF

GEOLOGICAL SURVEY
P. O. BOX 1391

Juneau, Alaska

MINES AND PETROLEUM BULLETIN

December, 1963

Vol. XI

No. 12

\title{
MININIHG ACTIVITIES
}

Southwest - Cold weather forced the closing of dredging operations in the area about the tenth of November. Goodnews Bay Mining Co. closed their dredge at Platinum and New York-Alaska Gold Dredging Corp. closed their. operation at Nyacr: The Flat miners ceased mining a few weeks earlier.

The Red Devil Mine closed this fall when the summer's exploration program failed to develop more ore. Dorr Holloway, Mariano Jauncorena and Jack Neubauer, all of Red Devil, have taken a lease on part of the facilities and are in the process of cleaning out some of the high grade stopes.

Southcentral - Fritz Kalmbach's lease on the Ferri Mine was renewed by thi company. He has been drifting on a lead there for several years.

Northcentral - The Little squaw Mining Compary completed 880 feet of drifting plus additional drilling and surface work on the Mikado and wittle scuaw veins in the Chandalar.

Southeastern - John Brockway reports that the Chicago Alaska Conpany have shipped a cat and will start exploring the Baker Peak copper prospect on Chicagof Island next spring.

\section{CARVING STONE INFORMATION DESIRED}

Requests for good Alaska carving stone are stili being recelved: Any suitable rock such as soapstone or gypsun is desirable and anyone having a deposit of such should contact this offlce. A sample shoula be subitted so that it can be examined. The deposit should contain several hundred tons so that an industry can be formed. The University of Alaska was able tio purchase several hundred pounds from Lloyd Hill's soapstone occurrence on Grubstake Gulch in the willow Creek District north of Anchorage. A Bourice closer to southeastern is desirable.

\section{OIL NEWS}

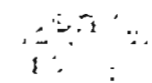

Drilling Activity:

\section{Operator}

Pan American

Colorado Oil a Gas corp.

Pan American

Pan American
We11 Number

Romig Park \#1

Gubik Unit \#1

Cook Inlet \#I

Middle Ground shoal \#2
Statua $11 / 26 / 63$

Drilling

Shut in Gas Well

Suspended

suspended 
Driling Activity (cont.)

Operator

Pan American

Pan American

Socal

Gulf Oil corp.

Superior

socal
Well Number $\therefore$

Cook Inlet \#IA (Relief weil) suspended Tyonek: State $\$ 2$

S.C.U. 23-3

Sandy River Federal \#I

Happy: Varluey Unst t:31-22

Naptowne Unit 24-8
Status $11 / 26 / 63$

Drilling

Producing $0 i l$ Well

Drilling

Drilling

Location

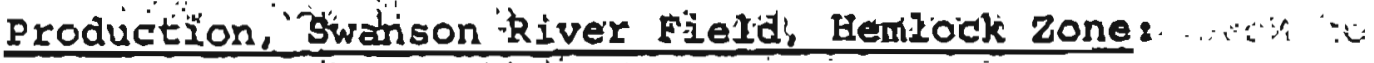

Producing Wells : Qil-Barrels : Gas (MCE)

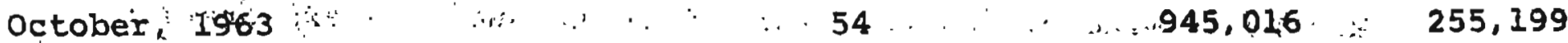

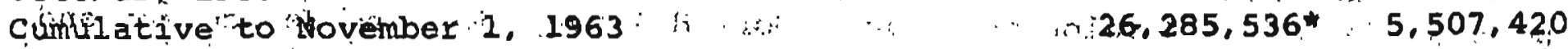

*Correction' previous month: from $25,330,520$ to $25,340,520 \%$. . . . .

Production, Kenai Gas Field:

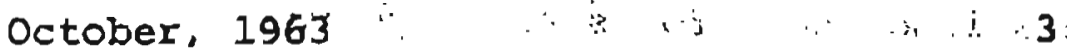

Cumulative to November 1,1963 : 236,330

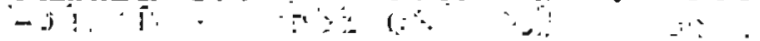

'production, SEexling Gas Field:

October, 1963

$, 005,862$

Cumull ative to Noviémber 1,1963

1

$\therefore:$

$\because$.

3,873
62,740

Production, Swanson River Gas Field, Kenai Zone:

October, 1963

6

476,501

Cumulative to November 1,1963

$4,080,878$

Gas Injektion, swâtion River Field, Hemlock Zone:

october.' 1963

Cumulative to November $1,1963 \ldots, \ldots$

$5,596,532$

*Correction previous month: from: 572,142 to 1572,192

Weather Closes Down Offshore Drilling Activity i The offshore drilling vessel CUSS II which drilled Shell Oil Company's Middle Ground shoal \#l has been returned to California and the wODECO II drilling vessel used at Pan American Petroleum Corporation's Cook Inlet State 1 and $1 \mathrm{~A}$ wells is tied up at

Seldovia for the winter. Also tied up at Seldovia is Western ofrabore: 'Dr Pling Company'; B Barge \#599 which tended the platforms from which Pan American'B Midalle "iround "shoal \#1 and \#2 were drilled. These platforms" have been bracus above the ice level and in a joint company project, instrument piles have been fastened to one platform to measure and record the otrains from the 
pounding by the cook Inlet ice flows. This is being done to gather data to : used in designing permanent platforms for drilling and producing development wells.

\section{COAL NEWS}

\section{MINEMOUTH PONER PLANT IOAN REQUESTED FOR HEALY}

The Golden Valley Electric Association plans to submit a loan request to the Rural Electrification Administration in Washington for a 22,000 kilowatt coal-fired minemouth plant in the Healy area. The cost is estimated at \$500,000. The GVEA had planned originally on a General Electric Nuclear plant; but GE has withdrawn from the small nuclear plant. business. Some feasibility studies have suggested minemouth power would be the most practical and likely less expensive for the Fairbanks area.

\section{A NEW USE FOR COAL}

A new potential market for up to 10 million tons of coal annualiy may be created if coal can be used to lower the cost of sewage and waste treat. ment processes. The Department of Interior announced a contract had been let between the Office of Coal: Research and the Rand Development: Corp. of cleveland for $\$ 164,000$ for research into the properties of coal as an bsorbent, settling agent, flocculent, and filter aid to determine if coal -an be used for treating sewage and industrial waste.

\section{NORTHWEST MINING ASSOCIATION}

The 69th Annual Convention of the Northwest Mining Association will be on December 6th and 7th at the Davenport Hotel in Spokane. Sessions will start at 9:30 a:m. Friday the 6th. The first session will be of general interest and include discussions on the mining industry of the U.S. and Canada including revision of Public Land Laws. There will be three sessions in the afternoon: one entitled Canadian, one Gold-silver, and one Finance and Taxation.

Saturday, December 7th, sesslons will be held during the morning on, Milling, Geology, Land and Mining Law. During the afternoon sessions will be held on Mining and Geology.

The list of speakers is impressive. It includes top men of the mining industry. as well as from the fields of banking, law, arid government. As Alaska's regulations for mining on state-owned lands are probably, the most attractive of any of the States', Jim. Williams, Director of the DMsM, has been invited to present a paper entitled "Inducements to Encourage Discovery and Production on Alaska State Lands." 
NEW U. S. GEOLOGICAI SURVEY PUBLICATIONS

U. S. Geological Survey Profesisional Paper 475-C, the latest: issue of $a$ series of short papers in geology and hydrology. Several articles deal with Alaska:

Article 68 - Revised stratigraphic nomenclature and age of the Tuxedni Group in the cook Inlet region, Alaika, by Robert L. Detterman

Article 79 Possible Pleistocene - Recent boundary in the Gulf of Alaska, based on benthonic Foraminifera by Patsy. B. Smith

Article 91 - Glaciolacustrine diamicton deposits in'the Cooper. River Basin, Alaska, by Oscar J. Ferrians, Jr.

Geology of the Freshwater. Bay Area Chichagof Island, Alaska, Bulletin 1108-C, by Robert A. Loney, William H. Condon, and J. Thomas Dutro, Jr. Gerieral geology of an area underlain largely by middle paleozoic rocks, with emphasis on stratigraphy, structure, and petrography:

The above Professional paper and Bulletin are available from the Superintendent' of Documents; $U$. S. Government Printing Office, Washington, D. C.

REPORT RECOMMENDING CHANGES IN SAFETY STANDARDS FOR METAI MINES AVAIIAALE.

kecomendations for improving safety and health standards in the Nation's metallic and nonmetallic mining industry have been submitted in a report to Congress by Secretary of the Interior stewart $I$. Udall, following an intensive study authorized in 1961 under Public Law 87-300. The recommendations would affect over 200,000 workers throughout the Nation and are contained in a two-volume report covering all mineral mining activity, except coal and lignite. The report was prepared by a Mine safety study Board and the Bureau of Mines. Copies of the report are available for inspection at the Mine Safety Study Board, Room 5546, Department of the Interior. Waskingtoin; D. C.

\section{MUSKEG TRACTOR}

I. N. Wobdinan reports he purchased a small Muskeg Tractor for prospecting, and is quite pleased with its ability to get into the back country. He took a trip to his prospect at the head of Hurtle "creek the latter part of August. Freight hauled on the trip was the first by mechanical means to reach the prospect. He experienced no difficulty going over rocky ground or through the swamps, and he is anxious to try it this winter on the snow. 
The American Mining Congress "News Bulletin" reports several new and revised bills have been introduced in the House to establish a national wilderness preservation system which would safeguard, to a limited extent, application of the general mining laws to lands initially included in the wilderness system. The system initially would include all areas within the nationel forests classified as "wilderness" (presently 6, 409, 284 acres) "wild" (presently 1,165,523 acres) and "canoe" (some 1 million acres.). Under these measures, the Secretary, of Agriculture would be required, within 10 years of the bill's enactment, to review each "primitive" area in the national forest as, to its suitability for preservation as wilderness: and to report his findings to the President. The President would then advise! Congress and his recommendations would become effective only if so provided by an Act of Congress. Of particular interest are the legislation's following special provisions:

\begin{abstract}
"Notwithstanding any other provisions of the Act, until midnight. December 31, 1973, laws of the United states pertaining to mineral leasing and mining shall, to the same extent as applicable prior to the effective date of the Act, extend to those lands designated by the Act as "wilderness areas"; subject, however, to such reasonable regulations governing ingress and egress as may be prescribed by the secretary of Agriculture consistent with the use of the land for mineral location and development and exploration, drilling, and production, and use of land for transmission lines, water-lines, telephone lines, or facilities necessary in exploring, drilling, producing, mining, and processing operations, including where essential the use of mechanized ground or air equipment, and restoration as near as practicable of the surface of the land disturbed in performing prospecting, location, and in oil and gas leasing, discovery work exploration, drilling, and production, as soon as they have served theix purpose."
\end{abstract}

\begin{abstract}
"Within ten years after the effective date of this Act the secretary of the Interior shall review roadless portions of parks, monuments, and other units of the national park system, and portions of wildlife refuges and game ranges under the jurisdiction of the Secretary of the Interior on the effective date of this Act and shall report to the President his recommendations as to the suitability of each such portion for preservation as wilderness. The President shall advise the United states senate and the House of Representatives of his recommendations with respect to the designation as wilderness of each such portion for which review has been completed, together with maps and definitions of boundaries. Each such recommendation shall become effective only if so provided by an Act of Congress."
\end{abstract}

Mining locations and patents to mining claims would be permitted during the ten year period. 
E. AND M. J. METAL MARKET PRICES

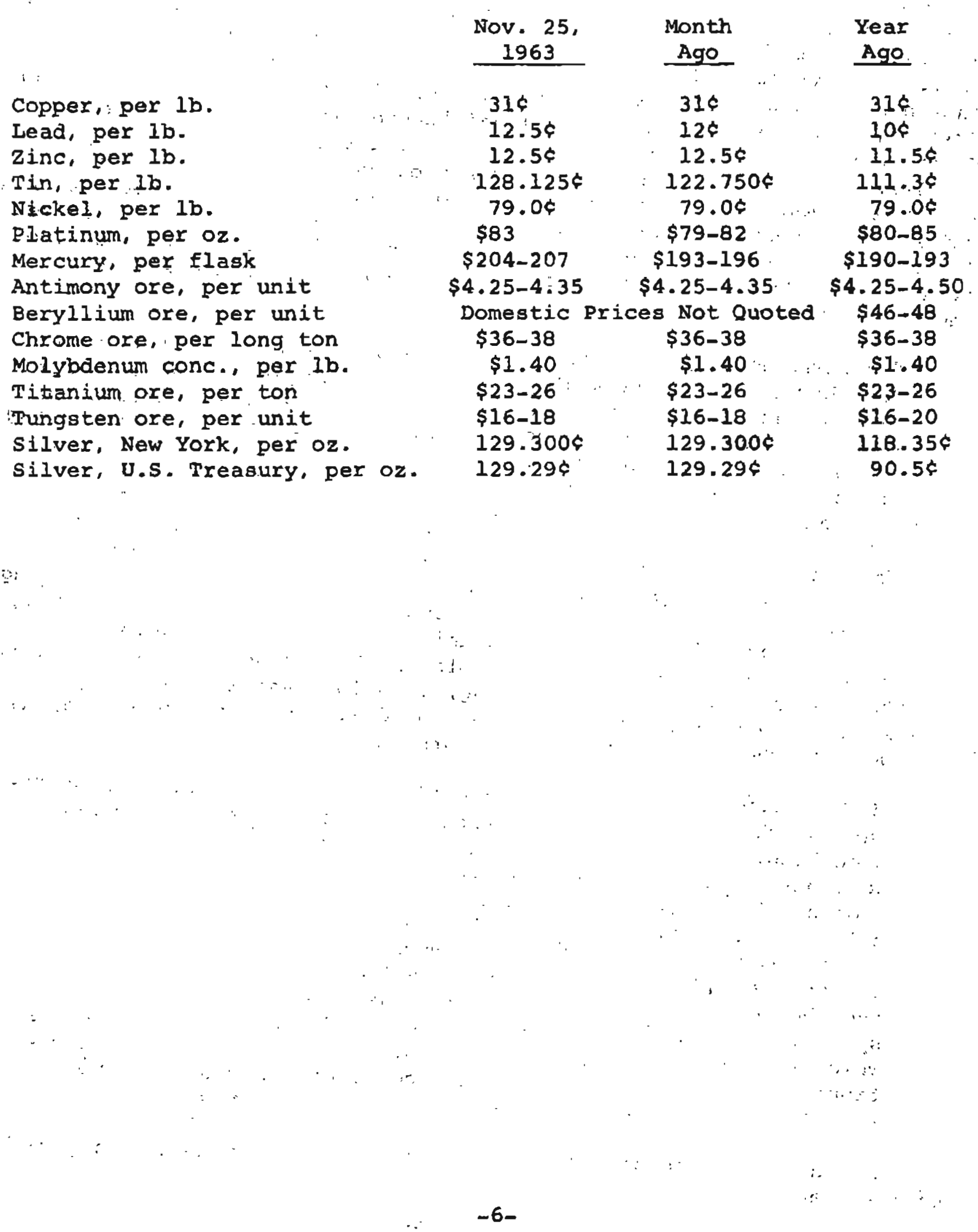

